\title{
UJI AKTIVITAS ANTIBAKTERI EKSTRAK ETANOL DAUN AFRIKA (Vernonia amygdalina Delile) ASAL PAPUA TERHADAP BAKTERI Staphylococcus aureus DAN Escherichia coli
}

\section{ANTIBACTERIAL ACTIVITY OF ETHANOLIC EXTRACT OF Vernonia amygdalina Delile LEAVES AGAINST Staphylococcus aureus AND Escherichia coli}

\author{
Rani Dewi Pratiwi, Elsye Gunawan \\ Program Studi Farmasi, Fakultas MIPA, Universitas Cenderawasih, Jayapura \\ Kampus Uncen Waena, Jl. Perumnas III Waena-Jayapura Papua 99351, Indonesia \\ Email: ranidp2987@gmail.com (Rani Dewi Pratiwi)
}

\begin{abstract}
ABSTRAK
Penelitian ini bertujuan untuk menguji efektifitas antibakteri ekstrak etanol daun afrika (Vernonia amygdalina Delile) terhadap bakteri Staphylococcus aureus dan Escherichia coli menggunakann metode difusi agar. Daun afrika asal Papua banyak dimanfaatkan di masyarakat lokal untuk pengobatan luka dan digunakan untuk menghilangkan jerawat. Daun afrika mengandung flavonoid, tannin, saponin, dan terpenoid. Pengambilan sampel dilakukan di Kota Jayapura, Papua. Lokasi penelitian dikerjakan di Laboratorium Program Studi Farmasi dan Laboratorium Biologi, Universitas Cenderawasih. Prosedur kerja meliputi pembuatan simplisia daun afrika, ekstraksi daun afrika, dan uji efektivitas antibakteri. Hasil pengujian aktivitas antibakteri pada konsentrasi paling rendah menunjukkan bahwa ekstrak daun afrika dapat menghambat pertumbuhan bakteri $S$. aureus dan $E$. coli sebesar $6,69 \mathrm{~mm}$ dan $6,52 \mathrm{~mm}$. Berdasarkan hasil analisis Beda Nyata Jujur (BNJ) tidak ada perbedaan yang nyata antara daya hambat pada masing-masing konsentrasi ekstrak daun afrika terhadap bakteri $S$. aureus dan E. coli, sehingga dengan konsenterasi paling kecil $(100 \mu \mathrm{g} / \mathrm{mL})$ telah memberikan aktivitas antibakteri terhadap bakteri S. aureus dan E. coli.
\end{abstract}

Kata kunci: antibakteri, Vernonia amygdalina Delile, Staphylococcus aureus, Escherichia coli.

\begin{abstract}
The aim of this study was to investigate the antibacterial activity of Vernonia amygdalina Delile (daun afrika) extract from Papua against Staphylococcus aureus and Escherichia coli by using agar diffusion methods. Afrika leaves from Papua is widely utilized by local people, one of them to the treatment of acne and wound healing. Previous researches demonstrated that daun afrika contained flavonoids, tannins, saponins, and terpenoids. In this study, sample was collected from Jayapura, Papua. The research was carried out at the Laboratory of Pharmacy and Laboratory of Biology,
\end{abstract}


Cenderawasih University. The procedures of this study included preparation of daun afrika crude drugs, extraction, and antibacterial activity test. The research result showed that the extract of daun afrika inhibited the growth of Staphylococcus aureus and Escherichia coli at concentration of $100 \mu \mathrm{g} / \mathrm{mL}$ with inhibition zone diameter of 6.69 and $6.52 \mathrm{~mm}$, respectively. The least significant difference test showed there was no different inhibition zone in each concentrations of daun africa extract against $S$. aureus and E. coli.

Key words: antibacterial, Vernonia amygdalina Delile, Staphylococcus aureus, Escherichia coli. 


\section{Pendahuluan}

Daun afrika (Vernonia amygdalina Delile) adalah tumbuhan semak atau pohon kecil yang tumbuh di daerah tropis Afrika. Tumbuhan ini mencapai ketinggian 2,5 m dengan diameter sekitar $6 \mathrm{~mm}$ (Ijeh dan Ejike, 2011). Tumbuhan ini mempunyai cabang-cabang yang rapuh dan mudah patah. Tumbuhan ini mempunyai bentuk daun elips dengan panjang mencapai 20 $\mathrm{cm}$ serta mempunyai rambut lembut di bagian bawah. Tumbuhan ini mempunyai daun berwarna hijau dengan bau yang khas dan rasa pahit (Gambar 1), serta mempunyai bunga berwarna putih, kecil, dan berkerumun (Mbinglo, 1998).

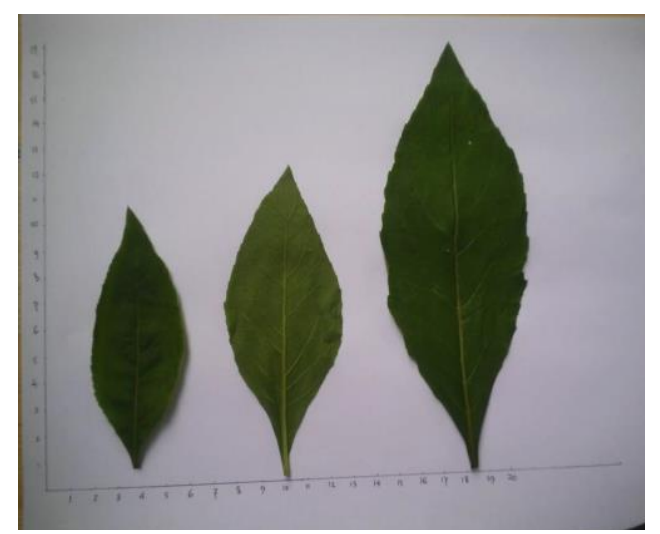

Gambar 1. Daun afrika (Vernonia amygdalina Delile).

Tumbuhan afrika mengandung flavonoid, tannin, saponin, dan terpenoid yang mampu membunuh parasit penyebab schistosomiasis, malaria leishmaniasis, antiamoeba, antitumor, dan antimikroba. Selain itu, daun afrika mempunyai manfaat untuk diabetes, malaria, menstabilkan tekanan darah, membantu menyembuhkan insomnia, membantu mencegah penyakit stroke, mencegah kanker, dan mencegah penyakit jantung (ljeh dan Ejike, 2011).

$$
\text { Indonesia merupakan negara }
$$
yang beriklim tropis, sehingga bakteri akan mudah tumbuh subur di Indonesia termasuk di antaranya, jenis bakteri yang bersifat patogen. Penyakit yang disebabkan oleh bakteri menjadi masalah cukup serius karena menyebabkan berbagai ganguan, seperti infeksi kulit, infeksi usus, infeksi saluran pencernaan, dan infeksi saluran pernapasan. Pengobatan penyakit infeksi bakteri menggunakan antibiotik. Masalah lain yang timbul akibat penggunaan antibiotik adalah resistensi bakteri terhadap antibiotik yang mulai tinggi akibat penggunaan antibiotik yang irrasional dan toksisitas beberapa antibiotik terhadap tubuh.

Oleh sebab itu pada penelitian ini akan dilakukan uji efektifitas antibakteri ekstrak etanol daun afrika. 
Pemilihan jenis bakteri untuk mewakili bakteri gram positif yaitu S.aureus dan bakteri gram negatif diwakili oleh $E$. coli. Kedua jenis bakteri tersebut merupakan bakteri yang paling sering menyebabkan gangguan kesehatan pada manusia yaitu S. aureus dapat menyebabkan infeksi kulit, sedangkan E. coli dapat menyebabkan diare dan infeksi saluran kemih (Jawetz et al., 2007).

\section{Metode Penelitian}

\section{Alat dan Bahan}

Alat yang digunakan dalam penelitian ini adalah oven, aluminium foil, timbangan analitik, blender, ayakan mesh 65 , bejana kaca, batang pengaduk, gelas ukur, kertas saring whatman no.42, corong, gelas kimia, kamera, rotary evaporator, waterbath, pot krim, hot plate, laminar air flow, inkubator, bunsen, cawan petri, kaca transparan, $\mathrm{pH}$ meter universal, autoklaf, sentrifugator. Sedangkan bahan yang digunakan adalah simplisia daun afrika, etanol 96\%, kloramfenikol (antibiotik pembanding), media NA (Nutrient Agar), dan media MHA (Mueller Hinton Agar), dimetilsulfoksida (DMSO) 10\%, isolat murni bakteri S. aureus dan E. Coli.

\section{Jalannya Penelitian}

1. Pembuatan simplisia

Tumbuhan afrika dibersihkan dari kotoran yang melekat, dicuci dengan air, dikeringkan dengan cara diangin-anginkan. Daun afrika yang sudah kering diblender hingga menjadi serbuk. Serbuk yang didapat kemudian disimpan dalam wadah bersih dan tertutup rapat.

2. Pembuatan ekstrak daun afrika Sebanyak 300 g serbuk daun afrika dimasukkan ke dalam botol kimia, kemudian ditambahkan pelarut etanol $96 \%$ sebanyak $2,7 \mathrm{~L}$, ditutup, dan dibiarkan selama 3 hari terlindung dari cahaya. Setelah 3 hari, rendaman disaring sebagai filtrat kemudian diuapkan dengan dengan rotary evaporator pada suhu $40{ }^{\circ} \mathrm{C}$ sampai didapat ekstrak pekatnya.

3. Skrining fitokimia ekstrak daun afrika

Skrining fitokimia dilakukan terhadap ekstrak daun afrika meliputi pemeriksaan terhadap golongan saponin, tanin, flavonoid, alkaloid, kuinon, triterpenoid, dan steroid.

4. Pengujian aktivitas antibakteri ekstrak etanol daun afrika

Uji aktivitas antibakteri ekstrak etanol daun afrika, kontrol negatif, dan kontrol positif menggunakan 
metode Disc Diffusion Kirby-Bauer secara in vitro terhadap bakteri $S$. aureus dan E. coli. Ekstrak etanol dibuat dalam lima seri konsentrasi yaitu 100, 250, 500, 750, dan 1000 ppm (Gambar 2). Media yang digunakan yaitu media MHA. Kertas cakram dicelupkan dalam ekstrak etanol daun afrika kemudian ditempatkan di atas permukaan media yang telah ditumbuhkan bakteri. Cawan petri diinkubasi pada suhu 37 ${ }^{0} \mathrm{C}$ selama 24 jam, kemudian diamati zona hambat yang terbentuk. Kontrol negatif yang digunakan adalah akuades sedangkan kontrol positif yang digunakan adalah antibiotik ciprofloksasin.

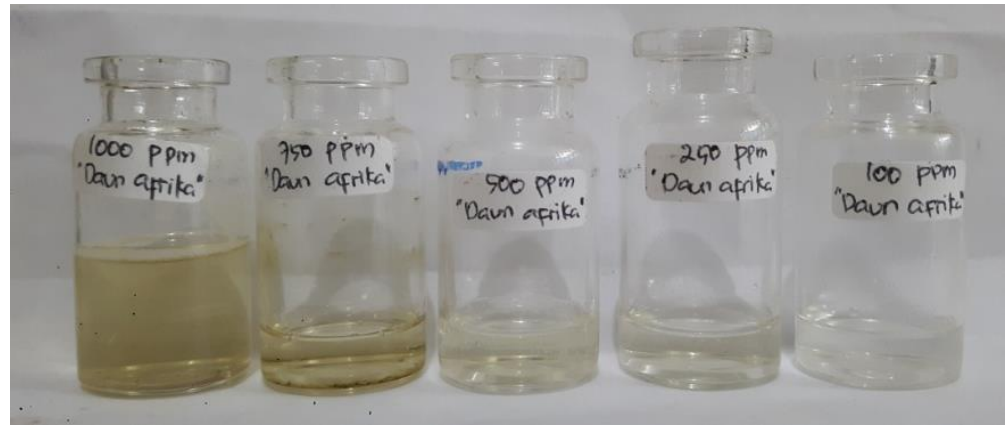

Gambar 2. Seri konsentrasi larutan uji ektrak etanol daun afrika.

\section{Hasil dan Pembahasan}

Berdasarkan hasil skrining fitokimia, ekstrak etanol daun afrika menunjukkan adanya senyawa golongan flavonoid, tanin, dan steroid. Hasil skrining fitokimia ekstrak etanol daun afrika dapat dilihat pada Gambar 3 dan Tabel 1. Pada prinsipnya metabolit sekunder suatu tanaman tergantung dari faktor biotik (herbivora, patogen, polinator, dispersi biji, simbion) dan faktor abiotik (cahaya, temperatur, air, nutrisi) (Castro et al., 2005). Produk sekunder tanaman dapat bervariasi tergantung paparan selama pertumbuhan tanaman, tempat tumbuh dan kebutuhan tanaman tersebut. 


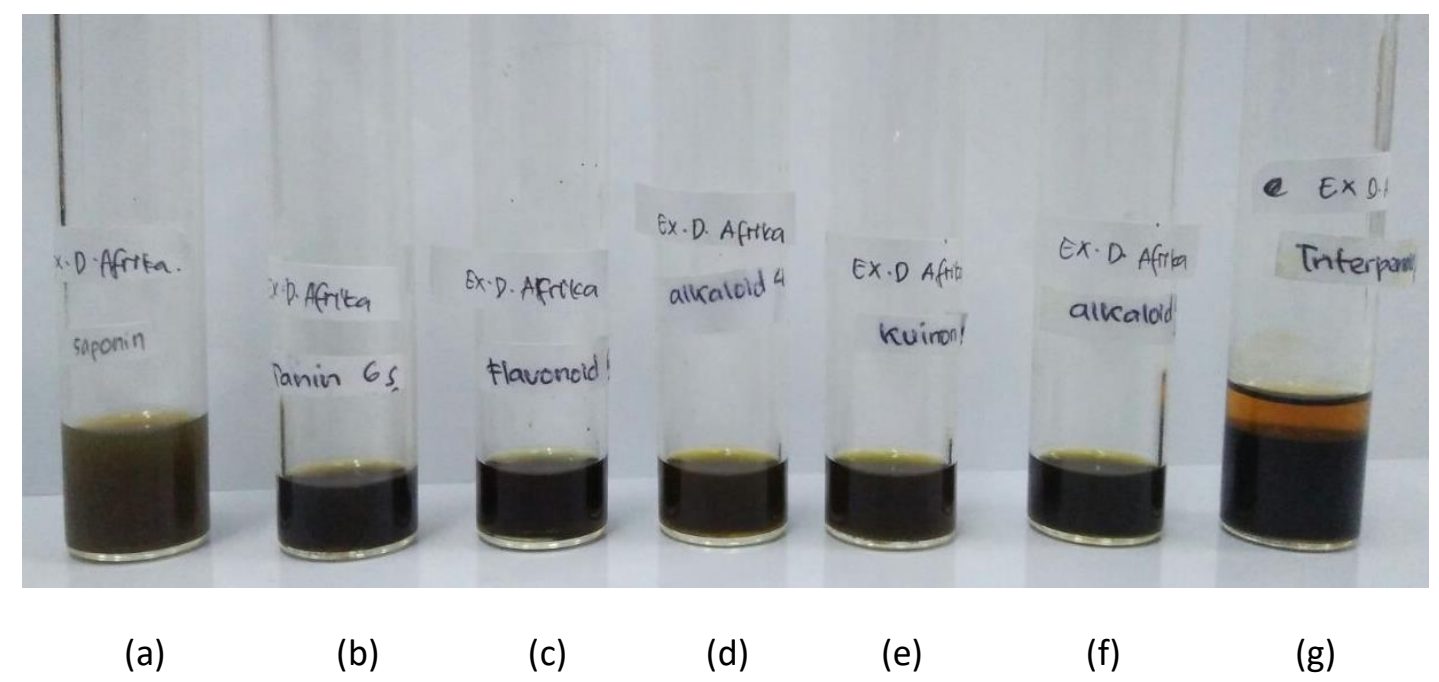

Gambar 3. Hasil skrining fitokimia ekstrak daun afrika

Tabel 1. Hasil skrining fitokimia ekstrak daun afrika

\begin{tabular}{lc}
\hline Metabolisme Sekunder & Ekstrak \\
\hline Saponin & Negatif \\
Tanin & Positif \\
Flavonoid & Positif \\
Alkaloid & Negatif \\
Kuinon & Negatif \\
Triterpenoid & Negatif \\
Steroid & Positif \\
\hline
\end{tabular}

Hasil pengujian aktivitas coli sebesar $6,69 \mathrm{~mm}$ dan $6,52 \mathrm{~mm}$, antibakteri ekstrak daun afrika terhadap berdasarkan kriteria daya hambat bakteri S.aureus dan E. coli dapat dilihat menurut Davis dan Stout (1971), kriteria pada Tabel 2, Gambar 4, dan Gambar 5. lemah jika daya hambat $>5 \mathrm{~mm}$, sedang Berdasarkan hasil yang diperoleh, jika daya hambat 5-10 mm, kuat jika diketahui bahwa pengujian terhadap daya hambat 10-20 $\mathrm{mm}$ dan sangat kuat kontrol negatif (akuades) adalah $0 \mathrm{~mm}$, jika daya hambatnya $>20 \mathrm{~mm}$. Daya sedangkan pada kontrol positif hambat ekstrak daun afrika terhadap (ciprofloksasin $5 \mu \mathrm{g}$ ) adalah 31,84 mm. bakteri S. aureus dan E. coli pada Pada konsentrasi paling rendah ekstrak konsentrasi 100, 250, 500, 750, dan 1000 daun afrika dapat menghambat ppm termasuk kategori sedang. pertumbuhan bakteri $S$. aureus dan $E$. 
Vol. 15 No. 02 Desember 2018

Tabel 2. Aktivitas antibakteri ekstrak daun afrika terhadap bakteri S.aureus dan E. coli

\begin{tabular}{ccc}
\multirow{2}{*}{ Konsentrasi $(\mu \mathrm{g} / \mathrm{mL})$} & \multicolumn{2}{c}{ Rata-Rata Daya Hambat $(\mathbf{m m})$} \\
\cline { 2 - 3 } & S. Aureus & E. coli \\
\hline K (-) & $0^{\mathrm{a}}$ & $0^{\mathrm{a}}$ \\
100 & $6,69^{\mathrm{b}}$ & $6,52^{\mathrm{b}}$ \\
250 & $7,04^{\mathrm{b}}$ & $6,61^{\mathrm{b}}$ \\
500 & $7,12^{\mathrm{b}}$ & $6,63^{\mathrm{b}}$ \\
750 & $7,31^{\mathrm{b}}$ & $6,64^{\mathrm{b}}$ \\
1000 & $7,56^{\mathrm{b}}$ & $6,74^{\mathrm{b}}$ \\
$\mathrm{K}(+)$ & $21,50^{\mathrm{c}}$ & $31,84^{\mathrm{c}}$ \\
\hline
\end{tabular}

Keterangan: notasi $(a, b, c)$ merupakan hasil dari uji BNJ dengan taraf kepercayaan 5\%, apabila notasi uji BNJ sama menunjukkan tidak ada beda nyata dan bila tidak sama menunjukkan perbedaan nyata.

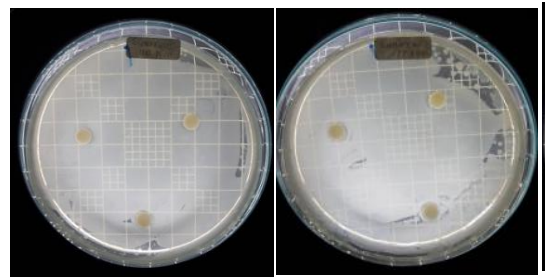

(a) (b)

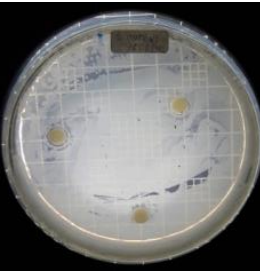

(c)

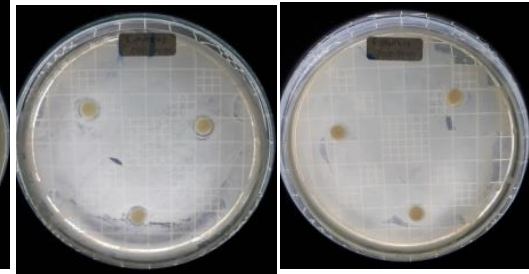

(d) (e)

Gambar 4. Uji daya hambat pada bakteri S. Aureus (a) $100 \mu \mathrm{g} / \mathrm{mL}$ (b) $250 \mu \mathrm{g} / \mathrm{mL}$ (c) 500 $\mu \mathrm{g} / \mathrm{mL}$ (d) $750 \mu \mathrm{g} / \mathrm{mL}$ (e) $1000 \mu \mathrm{g} / \mathrm{mL}$.

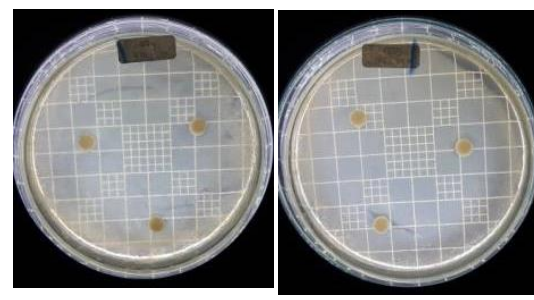

(a) (b)

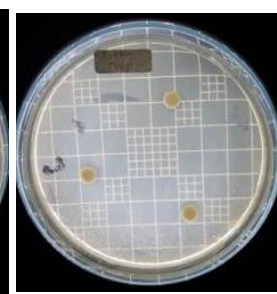

(c)

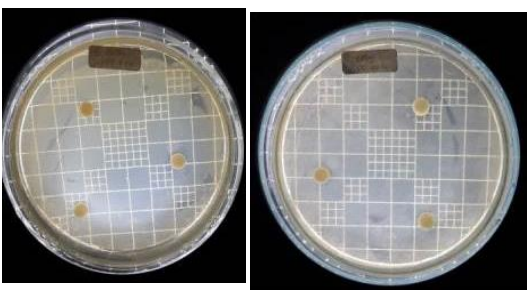

(d)

(e)

Gambar 5. Uji daya hambat pada bakteri E. coli (a) $100 \mu \mathrm{g} / \mathrm{mL}$ (b) $250 \mu \mathrm{g} / \mathrm{mL}$ (c) 500 $\mu \mathrm{g} / \mathrm{mL}$ (d) $750 \mu \mathrm{g} / \mathrm{mL}$ (e) $1000 \mu \mathrm{g} / \mathrm{mL}$. 
Data daya hambat ekstrak daun afrika terhadap bakteri S. aureus dan $E$. coli selanjutnya dianalisis menggunakan Anova One Way kemudian dilanjutkan dengan Uji BNJ. Berdasarkan hasil analisis BNJ tidak ada perbedaan yang nyata antara daya hambat pada masingmasing konsentrasi ekstrak daun afrika terhadap bakteri S. aureus dan E. coli, sehingga dengan konsentrasi paling kecil $(100 \mu \mathrm{g} / \mathrm{mL}$ ) telah memberikan aktivitas antibakteri terhadap bakteri $S$. aureus dan E. coli.

Hasil uji aktivitas antibakteri menunjukkan bahwa ekstrak etanol daun afrika dapat menghambat pertumbuhan bakteri S. aureus dan $E$. coli. Hal tersebut disebabkan oleh kandungan senyawa pada ekstrak yang berperan sebagai antibakteri. Senyawa tersebut di antaranya adalah flavonoid. Mekanisme kerja flavonoid sebagai antimikroba dapat dibagi menjadi 3 yaitu menghambat sintesis asam nukleat, menghambat fungsi membran sel, dan menghambat metabolisme energi (Hendra et al., 2011). Flavonoid merupakan senyawa fenol (Harbone, 1987). Flavonoid menyebabkan terjadinya kerusakan permeabilitas dinding sel bakteri, mikrosom, dan lisosom sebagai hasil interaksi antara flavonoid dengan DNA bakteri (Cushine et al., 2005). Mekanisme kerja flavonoid dalam menghambat fungsi membran sel adalah dengan membentuk senyawa kompleks dengan protein ekstraseluler dan terlarut sehingga dapat merusak membran sel bakteri dan diikuti dengan keluarnya senyawa intraseluler (Nuria et al., 2009). Flavonoid dapat menghambat metabolisme energi dengan cara menghambat penggunaan oksigen oleh bakteri. Flavonoid menghambat pada sitokrom C reduktase sehingga pembentukan metabolisme terhambat. Energi dibutuhkan bakteri untuk biosintesis makromolekul (Cushine et al., 2005).

Senyawa lain yang diduga berperan sebagai antibakteri adalah tanin dan steroid. Tanin memiliki peran sebagai antibakteri dengan cara mengikat protein sehingga pembentukan dinding sel akan terhambat (Masduki, 1996). Efek antibakteri tanin adalah melalui reaksi dengan membran sel, inaktivasi enzim, dan inaktivasi fungsi materi genetik. Mekanisme kerja tanin sebagai antibakteri adalah menghambat enzim reverse transkriptase dan DNA topoisomerase sehingga sel bakteri tidak dapat terbentuk (Nuria et al., 2009). Tanin memiliki aktivitas antibakteri yang 
Vol. 15 No. 02 Desember 2018

berhubungan dengan kemampuannya untuk menginaktifkan adhesin sel mikroba, menginaktifkan enzim, dan mengganggu transport protein pada lapisan dalam sel (Cowan, 1999). Tanin juga mempunyai target pada polipeptida dinding sel sehingga pembentukan dinding sel menjadi kurang sempurna. Hal ini menyebabkan sel bakteri menjadi lisis karena tekanan osmotik maupun fisik sehingga sel bakteri akan mati (Sari dan Sari, 2011). Kompleksasi dari ion besi dengan tanin dapat menjelaskan toksisitas tanin. Mikroorganisme yang tumbuh di bawah kondisi aerobik membutuhkan zat besi untuk berbagai fungsi, termasuk reduksi dari prekursor ribonukleotida DNA. Enzim reverse transkriptase dan DNA topoisomerase sel bakteri tidak dapat terbentuk oleh kapasitas pengikat besi yang kuat oleh tanin (Akiyama, 2001). Mekanisme steroid sebagai antibakteri berhubungan dengan membran lipid dan sensitivitas terhadap komponen steroid yang menyebabkan kebocoran pada ribosom (Madduluri et al., 2013). Steroid dapat berinteraksi dengan membran fosfolipid sel yang bersifat permeabel terhadap senyawa-senyawa lipofilik sehingga menyebabkan integritas membran menurun serta morfologi membran sel berubah yang menyebabkan sel rapuh dan lisis (Ahmed, 2007).

\section{Daftar Pustaka}

Ahmed, B. 2007. Chemistry of Natural Products. New Delhi: Department of Pharmaceutical Chemistry Faculty of Science Jamia Hamdard.

Akiyama, H., Fujii, K., Yamasaki, O., Oono, T., Iwatsuki, K. 2001. Antibacterial action of several tannin against Staphylococcus aureus. Journal of Antimicrobial Chemotherapy, 48:487-491.

Castro, P.R.C., Kluge, R.A., Peres, L.E.P. 2005. Manual de Fisiologia Vegetal, Teoria e Prática. Piracicaba: Agronômica Ceres.

Cowan, M.M. 1999. Plant products as antimicrobial agents. Clinical Microbiology Reviews, 12:564582.

Cushnie, T.P., Lamb, A.J. 2005. Antimicrobial activity of flavonoids. International Journal of Antimicrobial Agents, 26:343-356.

Davis, W. dan Stout, T. 1971. Disc PITE methods of microbiological antibiotic assay. Microbiology, 22(4):659-665.

Harbone, J.B. 1987. Metode Fitokimia. Bandung: ITB Press.

Hendra, R., Ahmad, S., Sukari, A., Shukor, M.Y., Oskoueian, E. 2011. Flavonoid analyses and antimicrobial activity of various parts of Phaleria macrocarpa (Scheff.) Boerl fruit. International 
Journal of Molecular Sciences, 12:3422-3431.

Ijeh, I.L. dan Ejike, C.E.C.C. 2011. Current perspectives on the medicinal potentials of Vernonia amygdalina Del. Journal of Medicinal Plant Research, 5(7):1051-1061.

Jawetz, Melnick, dan Adelberg's. 2005. Mikrobiologi Kedokteran. Jakarta: Salemba Medika.

Madduluri, S., Rao, K.B., Sitaram, B. 2013. In vitro evaluation of antibacterial activity of five indegenous plants extract against five bacterial pathogens of human. International Journal of Pharmacy and Pharmaceutical Sciences, 5(4):679-684.

Masduki, I. 1996. Efek antibakteri ekstrak biji pinang (Areca cetuchu) terhadap S. aureus dan E. coli in vitro. Jurnal Cermin Dunia Kedokteran, 109:21-24.
Mbinglo, S. 1998. Surrel on the production of bitter leaf (Vernonia spp). In: Bamenda, A. (ed). North Western Cameroon: an NRI/Discharge University Student Project Report.

Nuria, M., Faizaitun, A.C., Sumantri. 2009. Uji aktivitas antibakteri ekstrak etanol daun jarak pagar (Jatropha curcas L) terhadap bakteri Staphylococcus aureus ATCC 25923, Escherichia coli ATCC 25922, dan Salmonella typhi ATCC 1408. Mediagro, 5(2):26-37.

Sari, F.P. dan Sari, S.M. 2011. Ekstraksi zat aktif antimikroba dari tanaman yodium (Jatropha multifida Linn) sebagai bahan baku alternatif antibiotik alami. Technical Report. Fakultas Teknik, Universitas Diponegoro. 